\title{
Assessment of Entrepreneurial Behavior Skills among Small Farmers: An Exploratory Study
}

\author{
John A. Agbolosoo' ${ }^{1}$, Richmond Anaman 2* \\ 1 Department of Agricultural Economics and Agribusiness Management, Faculty of \\ Agriculture, Egerton University, Njoro-Kenya \\ 2 School of Metallurgy and Environment, Central South University, Changsha, China \\ * Corresponding author: moseskwabenaanaman@gmail.com
}

\section{Article History \\ Received 2021-03-16 \\ Revised 2021-04-03 \\ Accepted 2021-04-16 \\ Published 2021-04-21}

\section{Keywords \\ Agribusiness \\ Entrepreneurial behavior \\ Enterprise \\ Smallholder \\ Potato farmer}

\section{How to cite?}

Agbolosoo, J. A., \& Anaman, R. (2021).

Assessment of Entrepreneurial Behavior

Skills among Small Farmers: An

Exploratory Study. SEISENSE Journal

of Management, 4(3), 17-33. doi:

10.33215 /sjom.v4i3.615
Aim - The study assessed the entrepreneurial behavior skills of smallholder potato farmers in Nakuru County, Kenya.

Methodology - A structured questionnaire was used to collect data. Data were collected from a total of 267 respondents using multistage sampling techniques. The principal component analysis was used to check the reliability and construct variability of entrepreneurial behavior skills. An entrepreneurial behavior index was generated to measure the behavior skills of smallholder potato farmers.

Findings - The results show that most smallholder potato farmers had a medium level of risk-taking ability, proactiveness behavior, innovativeness behavior, information-seeking behavior, cosmopoliteness behavior, and decision-making ability. The study concluded that this medium level of entrepreneurial behavior skills made smallholder potato farmers unable to perceive potato farming as a profitable and viable agribusiness venture.

Originality - The study recommends that entrepreneurial training with practical demonstration and effective communication skills should be used as an approach to empower and promote the development of entrepreneurial behavior qualities among smallholder potato farmers. 


\section{Introduction}

In the agriculture sector, entrepreneurial behavior is a psychological pathway and marketing strategy employed to improve sustainable growth and development of agribusiness performance (Kahan, 2013). Entrepreneurial behavior contributes to the personal development of an individual entrepreneurial farmer by making that person competent and innovative to thrive and survive in the farming business (Tamminana \& Mishra, 2017). Entrepreneurial behavior is the critical driver for the economic growth and development of the potato industry in Kenya. Its potential is to improve growth, increase wealth and quality of life among smallholder farmers. Smallholder farmers are the critical agripreneurs for promoting economic growth and development since agriculture is the main contributor to the Kenyan economy (GoK, 2012).

In Sub Saharan Africa, Kenya is the 5th most giant potato with an annual production of 1.4 million tons with a worth of Kenya Shillings 30 to 40 billion annually (KEPHIS, 2019). However, the potato has been identified as a suitable candidate for crop diversification in Kenya, providing a valuable source of income for subsistence farm households (Kaguongo et al., 2013). The potato industry contributes 1.9\% to agricultural gross domestic product (Mwangi, 2010) and provides farm income for 3.8 million smallholder farmers in rural settings (Okello et al., 2016). Despite the importance of potato farming through the provision of employment opportunities and increased incomes for smallholder farmers in the rural areas of Kenya (MOALFI, 2016). However, it has been stated that potato farming characterizes by several constraints leading to declining production and yields at a rate of $11 \%$ per year in Kenya (Kaguongo et al., 2013).

NPCK (2016) documented that the national average potato yield in Kenya is below 10t/ha against a potential of $40 \mathrm{t} / \mathrm{ha}-50 \mathrm{t} / \mathrm{ha}$, mainly due to poor-quality seeds and crop farming. This poor performance could be attributed to the illiteracy of smallholder farmers in adopting new seed varieties and following good agricultural practices. The inability of adopting improved seed varieties can be linked directly to farmers' poor entrepreneurial behavior skills such that these smallholder farmers are unwilling to take the risk of trying enhanced combinations and production techniques and making inappropriate production decisions by using their farmer saved seeds, which tend to increase pest and disease infestation resulting in low yields. Furthermore, past studies only focus on the poor performance of potato farming without linking it to entrepreneurial behavior skills. Therefore, there is little information on the entrepreneurial behavior skills of smallholder potato farmers in Kenya. The present study was undertaken to assess the entrepreneurial behavior of the smallholder potato farmers in Nakuru County.

\section{Literature Review}

Entrepreneurial behavior is simply a form of human behavior that involves identifying and exploiting business opportunities through the creation and development of new business ventures (Bhosale, Deshmukh, Godse, \& Shelake, 2014). Giridhara (2013) operationalized entrepreneurial behavior as the extent of qualitative and innovative activities carried out by an entrepreneur in his enterprise to increase production. Konté, Ayuya, and Gathungu (2019) conceptualized entrepreneurial behavior as the attitude, aptitude, and ability of the potential entrepreneurial farmer to discover and exploit available opportunities to establish a new agribusiness venture in a particular environment. According to Kahan (2013), entrepreneurial behavior is an inborn attitude that compels entrepreneurial farmers to be more technically competent and innovative to thrive and survive in the business environment since farm enterprises are operated within a complex and dynamic environment. This entrepreneurial behavior is influenced by individual, situational, psychological, social, and experiential factors (Kumar, Sharma, \& Yadav, 2013). This behavior drives an entrepreneurially oriented farmer to initiate, allocate, distribute and manage scarce economic resources to create and capture value to products and services within a dynamic agribusiness climate (Palma, 2009). In psychology, entrepreneurial behavior focuses on entrepreneurs' 
traits, i.e., achievement motivation, autonomy, self-confidence, self-motivation, risk-taking, proactiveness, innovativeness, decision-making, planning ability, coordinating ability, and information seeking.

According to Abeyrathne and Jayawardena (2014), entrepreneurial behavior contributes to developing an individual entrepreneurial farmer and drives that farmer to make a maximum profit from farm enterprise activities. It also helps agribusiness firms get more significant gain and grow simultaneously if they adopt competitive strategies. It also makes the firms use scarce resources efficiently and effectively to achieve superior performance. Owners of Agribusiness firms take these opportunities to develop and supply excellent products that meet customers' needs to create a competitive advantage (Omare, 2016). Entrepreneurial behavior creates an avenue for agribusiness to function well in an entrepreneurial environment. The entrepreneurial environment can positively or negatively influence the performance of agribusiness. Fayaz (2015) postulates that entrepreneurial skills influence successful smallholder farmers to perform better in the agribusiness environment, contributing to the economic growth and development of developing and developed economies. Entrepreneurial behavior can be considered smallholder farmers' ability to introduce new products to the market by taking calculated risks searching for information and making effective decisions concerning those products. Most smallholder farmers display common personal characteristics i.e. innovativeness, decisionmaking, and leadership, risk-taking, coordinating, planning and organizing ability, and allocating scarce resources to make them perform very well in farm enterprise activities (Mubeena, Lakshmi, Prasad, \& Sunitha, 2017). A study conducted by Khalid, Maalu, Gathungu, and McCormick (2016) provides more insight into entrepreneurial behavior. The study found that achievement needs, legitimacy-seeking behavior, and risk-taking ability as the significant determinants of high performance of micro and small livestock-based enterprises in the North Eastern Region of Kenya. Wanole, Bande, Holkar, and Mardane (2018) postulate that innovativeness, farm decision-making achievement motivation, information-seeking behavior, leadership ability, cosmopoliteness, and risk-taking ability of farmers play a significant role in increasing agricultural farms performance of micro and small banana-based enterprises in Uganda.

Rituraj, Borua, Deka, and Borah (2015) stated that most vegetable growers had a medium level of risk-taking ability, followed by high and low in the Jorhat District of Assam. Mubeena et al. (2017) found that rural women have a medium level of risk-taking ability followed by low and high. The main reason was that these women had a low socio-economic profile. They thought that taking risks would lead to low economic gain making them unable to introduce a transformation or change unless others tried and use them. Konté et al. (2019) explained that smallholder farmers are proactive in searching for active information and available opportunity in the agribusiness environment. Porchezhiyan, Devi, and Mathialagan (2014) also stated that information-seeking behavior had a positive and significant association with education, social participation, annual income, landholding, livestock possession, milk production, extension participation, knowledge of farm enterprise, and attitude towards dairy farming. The study employed the usage of social media platforms and mobile applications to access the information on potato farming from both formal and informal sources.

\section{Dimension of Entrepreneurial Behavior}

Entrepreneurial behavior consists of seven to thirteen elements: Achievement motivation, autonomy, innovativeness, proactiveness, and cosmopoliteness behavior, decision-making ability, and locus of control, information-seeking behavior, risk-taking propensity and self-efficacy, self-confidence, coordinating, and planning capacity. These components are perceived differently by researchers (Mudiwa, 2018). This study is limited to six significant elements, which are mostly use in entrepreneurship studies. Those dimensions include risk-taking, proactiveness, innovativeness, information-seeking behavior, cosmopoliteness, and decisionmaking ability behavior. 


\section{Risk-taking ability}

The ability to take calculated risk is used to describe the trade-off between accepting a higher chance to gain higher profits (Jelle, 2016). These risks include psychological risk, production risk, marketing, and financial risk. In most agriculture fields, the main risks that affect farmers are production and marketing risks. Mubeena et al. (2017) cited that rural women had a medium level of risk-taking ability followed by low and high. The main reason was that these women had a low socio-economic profile. They thought that taking risks would lead to low economic gain making them unable to take risks to introduce a transformation or change unless others tried and use them. This study used risk-taking behavior is as a pathway to provide a competitive advantage and increase the performance of potato farms. The risk-taking components used in the study were on the application of new seed varieties and new potato production techniques.

\section{Proactiveness behavior}

Proactive behavior is a term used to describe the ability to take initiatives by anticipating and pursuing new opportunities and participating in emerging markets Vora, Vora, and Polley (2012). Okangi (2019) noted that a business firm that follows the proactive approach in the market continuously seeks to bring improvements in its operations by acquiring entrepreneurial knowledge. It drives firms to become market leaders because of their early responsiveness to market signals. An entrepreneurial farmer looks for more agribusiness opportunities and seizes them while seeking relevant information to introduce new products and services ahead of his competitors. The study used identification and exploitation of new market opportunities ahead of competitors and tried new production techniques before other potato growers as proactiveness behavior.

\section{Innovativeness behavior}

Innovativeness is considered the ability of potential smallholder farmers to introduce new products and services in a perfectly competitive farm market. An innovative farmer search and exploit agribusiness opportunities to bring out new farm products to satisfy customers in the market place (Jelle, 2016). Innovative smallholder farmers have creative spirits and willingness to introduce new products and services in a competitive environment. They are resource people, and valuable assets recognize by the business community. Innovativeness behavior can influence entrepreneurial farmers to create a competitive advantage leading to the high performance of potato farms. Innovative farmers have creative spirits and a willingness to introduce new products and services in a competitive environment. Mubeena et al. (2017) observed that the majority (69.16\%) of the respondents had a medium level of innovativeness behavior followed by low $(18.34 \%)$ and high $(12.50 \%)$. The possible reason is that members avoided making a change since they were not prepared to make an effort in introducing new products in the market because of their low educational and economic status. In this study, trying locally available materials to control weeds, pests, and diseases were used as the innovative behavior of potato growers.

\section{Information-seeking behavior}

This is the personal attitude and behavior of an individual farmer to search for reliable information outside the farm enterprise environment to gain a competitive advantage and increase farm performance. Mariammal and Seethalakshmi (2017) postulated that the majority $(77.33 \%)$ of the women dairy farmers had a medium level of information-seeking behavior accompanied by low (11.67\%) and high (11\%) levels of information-seeking behavior. The trend might be that the farmers were educated, had access to extension agency contact, training, and farming experience motivated them to contact extension scientists, extension personnel, and progressive farmers in their farming community to get dairy-related information to make the profitable enterprise agribusiness. The study employed the usage of social media platforms and mobile applications to access the information on potato farming from both formal and informal sources. 


\section{Cosmopoliteness behavior}

Cosmopoliteness is one of the aspects of entrepreneurial behavior that motivates an individual smallholder farmer to look for information outside the farm environment to create competitiveness and improve farm performance. Cosmopoliteness behavior drives entrepreneurs to join social groups within or outside their farming community. Porchezhiyan, Devi, and Mathialagan (2016) stated that most (80\%) dairy farmers had a high level of cosmopoliteness, followed by medium (10.8\%) and low (9.2\%) cosmopoliteness behavior in the Northern District of Tamil Nadu. This might be due to their better economic condition, personal interest, and active participation in extension activities. In this current study, seeking information outside the farming community, agricultural workshops, and fields would make smallholder potato farmers gain more knowledge on potato farm management.

\section{Decision-making ability}

An entrepreneurial farmer can select the best choice among the alternative and available options concerning farm enterprise activities to build and maintain a sustainable competitive advantage through an effective decision-making process. A study conducted by Rituraj et al. (2015) reported that most of the vegetable growers had moderate (68.34\%) decision-making ability followed by poor (17.5\%) and sound (14.16\%) decision-making ability in the Jorhat District of Assam. The reason for having moderate decision-making ability was good education level, medium family size, small land holding, and high annual family income of vegetable growers. The study used decision-making ability as a crucial tool to build and maintain a competitive advantage and enhance the performance of small-scale potato enterprises in Nakuru County, Kenya. Growing certified seed potatoes and observing good agricultural practices were used as decision-making ability behavior of smallholder potato growers.

\section{Materials and Methods}

Nakuru County is one of the counties in Kenya which shares a border with eight counties and has eleven subcounties (GOK, 2018). The study was conducted in Nakuru County because it is regarded as the second-largest producer of potatoes in Kenya. A multistage sampling technique was used to sample 267 smallholder potato farmers. In the first stage, purposive sampling was employed to select Nakuru County due to its high potato farming activities in Kenya. Simple random sampling was used to determine three wards: Elburgon, Molo, and Turi in the second stage, where proportionate sampling was used to sample from each ward according to the proportion of potatoes produced and marketed in the third stage. Systematic sampling was used in the final stage, where every $25^{\text {th }}$ potato farmer on the list was picked as the respondent. The target population for the study was smallholder potato farmers who produced potatoes under five acres.

According to the agriculture officer, there are about 6,678 potato growers in Molo Sub-County, Nakuru, Kenya. The population formula proposed by Yamane (1967) was used to compute for sample size as follows:

$$
n=\frac{N}{1+N(e)^{2}}
$$

Where: $n=$ sample size, $\mathrm{N}=$ total population, and $e=$ marginal error $(6 \%)$

A well semi-structured questionnaire was used to elicit information from the respondents on a face-to-face basis with the help of trained enumerators. Data was collected on the socio-economic characteristics, entrepreneurial behavior skills of smallholder potato farmers. These behavior skills used in the study were risktaking ability, proactiveness, innovativeness, information-seeking behavior, cosmopoliteness, and decisionmaking ability. The behavior skills were measured on 5 points Likert scales ranging from strongly agree to disagree strongly. The data were analyzed using the Statistical Package for Social Sciences (SPSS) version 26. 
Descriptive statistics such as mean and standard deviation were computed for the Likert statements. Factor analysis was carried out to check the validity of the entrepreneurial behavior skills using the principal component analysis method with a Varimax rotation method in extracting skills. A total of six factors were being rotated. The Eigenvalues of six factors greater than one were also retained and accepted to represent the entrepreneurial behavior skills of smallholder potato farmers. Bartlett's sphericity, Cronbach alpha, and Kaiser-Meyer-Olkin (KMO) tests were carried out to detect the fitness of the entrepreneurial dimensions. Before finding the categories of entrepreneurial behavior skills, the principal component analysis was used to check the validity and reliability of estimated construct variables. The results from Bartlett's sphericity were $\left(x^{2}=1957.45, \mathrm{DF}=\right.$ $190, \mathrm{p}=0.00$ ) indicating that the behavior skills were suitable and fit for analysis. Cronbach alpha has a coefficient of 0.848 which means that the data was reliable for the study while Kaiser-Meyer-Olkin (KMO) was 0.810 , indicating that the sampling was adequate for principal component analysis (Dendup, Gyeltshen, Penjor, \& Dorji, 2017).

\section{Factor Analysis}

Factor Analysis is a statistical technique concerned with reducing observable variables in terms of a small number of latent factors, thus reducing a large number of variables to a smaller number of variables Field (, 2009). Guilford (1967) postulates that factor analysis has been developed to analyze the relationship among several measurable entities such as intelligence, behavior, and attitude. It attempts to identify underlying factors that explain the pattern of correlations within a set of observed variables. It is mainly used in data reduction to place a small number of factors that explain most of the variances observed in a much large number of manifest variables (Dillon \& Goldstein, 1984). According to Shrestha (2021), factor analysis is based on the assumption that all variables correlate to some degree and should be measured at the ordinal level.

\section{Cronbach Alpha}

The current study employs Cronbach alpha to examine the reliability of the questionnaire. It is used under the assumption that multiple items are measuring the same underlying construct. It is a measure of internal consistency between zero and one ( 0 and 1$)$ where a value more than 0.7 is considered acceptable in social science research. It is expressed as

$$
\alpha=\frac{\overline{n r}}{1+\bar{r}(n-1)}
$$

Where $\mathrm{n}$ represents the number of items and $\bar{r}$ is the mean correlation between the items.

\section{Kaiser-Meyer-Olkin (KMO)}

KMO test measures the suitability of data for factor analysis. This test measures sampling adequacy for each variable in the model and the complete model. The formula is given by:

$$
\mathrm{KMO}_{\mathrm{j}}=\frac{\sum_{i \neq j} R_{i j}^{2}}{\sum_{i \neq j} R_{i j}^{2}+\sum_{i \neq j} U_{i j}^{2}}
$$

Where $\mathrm{R}_{\mathrm{ij}}$ is the correlation matrix, and $\mathrm{U}_{\mathrm{ij}}$ is the partial covariance matrix. KMO value varies from 0 to 1 . The $\mathrm{KMO}$ values between 0.8 to 1 indicate that the sampling is adequate, values between 0.7 to 0.79 are tolerable, and values between 0.6 and 0.69 are mediocre. Values less than 0.5 indicate the sampling is not sufficient and remedial action should be taken. 


\section{Factor Extraction}

It encompasses determining the least number of factors that can best represent the interrelationships among a set of variables. The study used principal component analysis. In this study, Kaiser's criterion (eigenvalue) was used to decide the number of factors to retain in the factor analysis. The eigenvalue is a ratio between the common variance and the specific variance explained by a particular factor extracted. Pallant (2007) and Verma (2012) observed that the eigenvalue of a factor represents the amount of the total variance explained by that factor. Remarkable factors were having an eigenvalue more significant than one is retained in the analysis. Guttman (1954) and Kaiser (1970) considered eigenvalue more than one is substantial, and it indicates that more common variance that unique is explained by that factor.

The entrepreneurial behavior index was used to measure the entrepreneurial behavior of the respondents Rituraj et al. (2015). The formula is specified as:

$\mathrm{EBI}=\frac{\text { Obtained score by respondents }}{\text { Actual total score }} \times 100$

Where EBI = Entrepreneurial Behavior Index. Based on this index, the respondents were classified into three categories as given by:

Table 1: Description of measurement of entrepreneurial behavior skills

\begin{tabular}{cc}
\hline Category & Range \\
\hline Low & $(\bar{X}-S D)$ \\
Medium & $(\bar{X} \pm S D)$ \\
High & $(\bar{X}+S D)$ \\
\hline
\end{tabular}

\section{Pearson's coefficient of correlation}

The study used Pearson's coefficient technique to determine the relationship between socio-economic characteristics and entrepreneurial behavior skills. The formula is given by

$$
r=\frac{n \sum x y-\sum x \sum y}{\sqrt{n \sum x^{2}}-\left(\sum x\right)^{2} \cdot n \sum y^{2}-\left(\sum y\right)^{2}}
$$

where $r$ = correlation coefficient, $x=$ a score of independent variables, $y=$ a score of dependent variables and $n=$ the number of observations.

\section{Results and Discussion}

\section{Descriptive Statistics}

The socio-economic characteristics used in the present study were gender, age, marital status, education level, household size, annual income, and farming experience in potato farming.

Table 2: Socio-economic characteristics $(n=267)$

\begin{tabular}{llll}
\hline Personal profile & Category & Frequency & Percent \\
\hline Head of household & Self & 187 & 70 \\
& Spouse & 78 & 29.2 \\
\hline
\end{tabular}




\begin{tabular}{|c|c|c|c|}
\hline & Others & 2 & 0.7 \\
\hline \multirow[t]{2}{*}{ Gender } & Female & 139 & 52.1 \\
\hline & Male & 128 & 47.9 \\
\hline \multirow[t]{5}{*}{ Marital status } & Single & 43 & 16.1 \\
\hline & Married & 197 & 73.8 \\
\hline & Divorced & 7 & 2.6 \\
\hline & Widowed & 16 & 6 \\
\hline & Separated & 4 & 1.5 \\
\hline \multirow[t]{3}{*}{ Age } & Young (below 35 years) & 88 & 33 \\
\hline & Middle (36-55 years) & 123 & 46 \\
\hline & Old (above 55 years) & 56 & 21 \\
\hline \multirow[t]{4}{*}{ Level of education } & Informal & 11 & 4.1 \\
\hline & Primary & 148 & 55.4 \\
\hline & Secondary & 89 & 33.3 \\
\hline & Tertiary & 19 & 7.1 \\
\hline \multirow[t]{3}{*}{ Household size } & Small (1-5) & 194 & 72.7 \\
\hline & Medium (6-10) & 71 & 26.6 \\
\hline & Large (11-15) & 2 & 0.7 \\
\hline \multirow[t]{7}{*}{ Type of land ownership } & Self-owned & 99 & 37.1 \\
\hline & Family & 64 & 24 \\
\hline & Rented & 72 & 27 \\
\hline & Self-owned \& family & 1 & 0.4 \\
\hline & Self-owned \& rented & 14 & 5.2 \\
\hline & Family \& rented & 11 & 4.1 \\
\hline & Self-owned, family \& rented & 6 & 2.2 \\
\hline \multirow[t]{3}{*}{ Total land size } & Micro (below 1 acre) & 82 & 30.7 \\
\hline & Small (1.1-5 acres) & 164 & 61.4 \\
\hline & Medium (above 5 acres) & 21 & 7.9 \\
\hline \multirow[t]{3}{*}{ Annual income (KSH) } & Low (below 100,000) & 171 & 64.0 \\
\hline & Medium $(101,000-500,000)$ & 91 & 34.0 \\
\hline & High (above 500,000) & 5 & 2.0 \\
\hline \multirow[t]{3}{*}{ Farming experience } & Low (1-5 years) & 124 & 46.4 \\
\hline & Medium (6-10 years) & 63 & 23.6 \\
\hline & High (11 years \& above) & 80 & 30 \\
\hline \multirow[t]{3}{*}{ Scale of production } & Micro farming (below 1 acre) & 172 & 64.4 \\
\hline & Small farming (1.1-5acres) & 90 & 33.7 \\
\hline & Medium farming (above 5 acres) & 5 & 1.9 \\
\hline
\end{tabular}

Source: Field data (2019)

Table 2 indicates that $70 \%$ of the potato farmers used for the study were heads of farm households. This means that potato farming activities may increase since the farmers would make effective decisions regarding land usage. It was revealed that $51.7 \%$ of the respondents were females. This indicates that female potato farmers 
participate more in potato farming than male potato farmers in Molo Sub-County. According to Taiy et al. (2016), males participate more in potato farming activities in the Mauche ward of Nakuru County than females.

About $73.8 \%$ of these potato farmers were married and staying together with their partners. This means that married couples would make production decisions together and would aid in farming. The finding is consistent with Ondiba and Matsui (2019), who posit that more than half of entrepreneurs in Kakamega County were married, only a few were single and divorced. A similar result was found by (Giridhara 2013; Ram, Singh, Chaudhary, \& Jayarani, 2016).

It was observed that $46 \%$ of the potato farmers belonged to the middle age group ( 36 to 55 years). This indicates that the majority of the potato farmers were middle-aged farmers with low farming experience. Kumar et al. (2013) observed that most of the farmers were middle-aged with ages between 35-55 years, followed by old age above 55 years and youths below 35 .

Moreover, $55.4 \%$ of the smallholder potato farmers interviewed in the study had a primary level of basic education. It means that most respondents had formal education before venturing into potato farming. Taiy et al. (2016) also cited that most of the potato farmers in Mache Ward had primary education followed by secondary, no formal education and tertiary education.

The results in Table 2 reveal that about $72.7 \%$ of the potato farmers had a small household size below five members. This showed that most of the potato farmers had a small farm household size, and means that an increase in household size would serve as a source of labor in potato farming activities. Gurjar, Gour, Dwivedi, and Badodiya (2017) observed that most of the potato farmers had a medium family size, followed by small family size and large family size in the Morar district Madhya Pradesh. It can be deduced that $37.1 \%$ of the potato farmers owned their farmland with title deed. The results show that most of the lands were owned by the smallholder potato farmers themselves. This means that farmers can increase the use of these lands for potato farming activities.

About $61.4 \%$ of the potato farmers possessed small land sizes ranging from 1.1 acres to 5 acres. This shows that most of the potato farmers possessed and used small farmland in the study area. The results confirm Rituraj et al. (2015) findings that the majority of vegetable farmers owned small farmland followed by semi-medium farmland size, marginal farmland, and large farmland size in the Jorhat district of Assam.

Sixty-four percent of potato farmers earned farm income below KSH 100,000.00 (911.99 United States Dollars) annually from farming activities. This means that most respondents were not making a profit from farming due to their production scale and high production cost. Bhosale et al. (2014) cited that dairy farmers earned medium annual income in dairy farming.

The results from Table 2 further shows that about $46.4 \%$ of the potato farmers had low experience in potato farming below five years. This low farming experience in potato enterprises could be attributed to the scale of production. It may make a potato farmer not take risks, be innovative, seek more information, and make an informed decision concerning potato farming activities. The findings of this study agree with Kumar (2016) stated that more than half of smallholder farmers had low experience accompanied by medium experience and high farming experience.

About $64.8 \%$ of smallholder potato farmers cultivated potatoes in less than an acre of farmland. The study observed that most of the potato farmers incur a high cost of potato production since they farm on small farmlands. These make smallholder potato farmers have diseconomies of scale in potato production. The findings agree with the research conducted by Taiy et al. (2016), which observed that most potato farmers 
cultivated potato on less than one acre of farmland, followed by small farm size and medium potato farm size in Mauche Ward of Nakuru County.

\section{Factor Analysis}

Table 3: Eigenvalues and total variance explained by entrepreneurial behavior skills

\begin{tabular}{|c|c|c|c|c|c|c|c|c|c|}
\hline \multirow{2}{*}{$\begin{array}{l}\stackrel{\mathscr{E}}{0} \\
\tilde{0} \\
\stackrel{0}{0} \\
\dot{0}\end{array}$} & \multicolumn{3}{|c|}{ Initial Eigenvalues } & \multicolumn{2}{|c|}{$\begin{array}{l}\text { Extraction Sums } \\
\text { Loadings }\end{array}$} & \multirow{2}{*}{$\begin{array}{c}\text { of Squared } \\
\begin{array}{c}\text { Cumulative } \\
\%\end{array}\end{array}$} & \multicolumn{2}{|c|}{$\begin{array}{l}\text { Rotation Sums } \\
\text { Loadings }\end{array}$} & \multirow{2}{*}{$\begin{array}{c}\text { of Squared } \\
\begin{array}{c}\text { Cumulative } \\
\%\end{array}\end{array}$} \\
\hline & Total & $\begin{array}{c}\% \text { of } \\
\text { Variance }\end{array}$ & $\begin{array}{c}\text { Cumulative } \\
\%\end{array}$ & Total & $\begin{array}{c}\% \text { of } \\
\text { Variance }\end{array}$ & & Total & $\begin{array}{c}\% \text { of } \\
\text { Variance }\end{array}$ & \\
\hline 1 & 5.39 & 26.96 & 26.96 & 5.392 & 26.960 & 26.960 & 2.959 & 14.794 & 14.794 \\
\hline 2 & 2.18 & 10.90 & 37.86 & 2.180 & 10.900 & 37.860 & 2.778 & 13.890 & 28.684 \\
\hline 3 & 1.73 & 8.63 & 46.49 & 1.726 & 8.631 & 46.491 & 2.574 & 12.868 & 41.552 \\
\hline 4 & 1.49 & 7.47 & 53.96 & 1.493 & 7.465 & 53.956 & 1.655 & 8.274 & 49.826 \\
\hline 5 & 1.08 & 5.40 & 59.36 & 1.080 & 5.401 & 59.357 & 1.632 & 8.161 & 57.987 \\
\hline 6 & 1.01 & 5.06 & 64.41 & 1.011 & 5.057 & 64.414 & 1.285 & 6.427 & 64.414 \\
\hline 7 & 0.96 & 4.81 & 69.22 & & & & & & \\
\hline 8 & 0.82 & 4.10 & 73.32 & & & & & & \\
\hline 9 & 0.78 & 3.87 & 77.19 & & & & & & \\
\hline 10 & 0.66 & 3.30 & 80.49 & & & & & & \\
\hline 11 & 0.59 & 2.97 & 83.47 & & & & & & \\
\hline 12 & 0.55 & 2.74 & 86.21 & & & & & & \\
\hline 13 & 0.50 & 2.52 & 88.72 & & & & & & \\
\hline 14 & 0.46 & 2.32 & 91.04 & & & & & & \\
\hline 15 & 0.38 & 1.87 & 92.92 & & & & & & \\
\hline 16 & 0.33 & 1.66 & 94.58 & & & & & & \\
\hline 17 & 0.33 & 1.63 & 96.20 & & & & & & \\
\hline 18 & 0.30 & 1.51 & 97.71 & & & & & & \\
\hline 19 & 0.25 & 1.27 & 98.97 & & & & & & \\
\hline 20 & 0.21 & 1.03 & 100.00 & & & & & & \\
\hline
\end{tabular}

Extraction Method: Varimax rotation

Source: Field data (2019)

Table 3 demonstrates the eigenvalues, and total variance explained in the factor analysis. The present used principal component analysis as the extraction method of factor analysis. Twenty components were identified within the dataset before the extraction, after extraction, and Varimax rotation six distinct linear components within the dataset whose eigenvalue greater than one were retained, accounting for $64.14 \%$ of the total variance. The results indicate that $64.14 \%$ common variance shared by the 20 entrepreneurial behavior variables can be accounted for by six factors. This reflects the KMO value of 0.810 , which can be considered good and indicates that factor analysis is used for the entrepreneurial behavior variables. This initial solution suggests that the final solution will extract not more than six factors. The first component has explained $14.79 \%$ of total variance with an eigenvalue of 5.39. The second component has explained $13.89 \%$ variance with eigenvalue 2.18 while the third component has $12.86 \%$ variance with eigenvalue 1.73 , followed by the fourth component of $8.27 \%$ variance with eigenvalue 1.49 . The fifth component explained variance of $8.16 \%$ with eigenvalue 1.08 , and the sixth component explained variance $6.43 \%$ with eigenvalue 1.01 . 


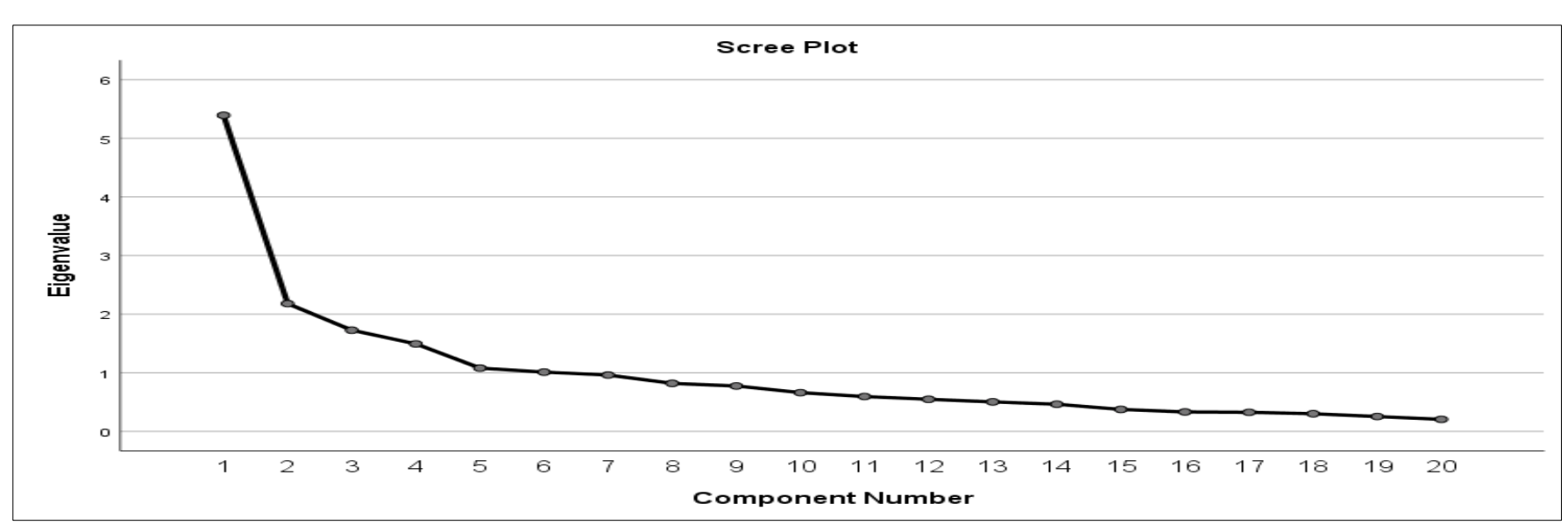

Figure 1: Scree plot for entrepreneurial behavior skills

Source: Field data (2019)

In Figure 1, the graphic is plotted with eigenvalues on the y axis against the twenty entrepreneurial behavior components on the x-axis. The initial factors extracted are significant factors with higher eigenvalues followed by smaller factors. The scree plot is used to determine the number of factors to retain in the analysis. The graph shows six factors for which the eigenvalue is more significant than one and accounts for most of the total variability in the data.

Table 4: Factor analysis on entrepreneurial behavior skills

\begin{tabular}{llllll}
\hline Dimensions & Factor loadings & Uniqueness & AIC & Alpha & KMO \\
\hline Risk-taking & 0.271 & 0.668 & 0.228 & 0.849 & 0.742 \\
RkS2 & 0.543 & 0.394 & 0.214 & 0.838 & 0.785 \\
RkS3 & 0.430 & 0.482 & 0.220 & 0.843 & 0.759 \\
RkS4 & 0.214 & 0.829 & 0.231 & 0.851 & 0.787 \\
Proactiveness & 0.621 & 0.392 & 0.211 & 0.836 & 0.820 \\
PrS2 & 0.681 & 0.355 & 0.208 & 0.833 & 0.842 \\
PrS3 & 0.550 & 0.488 & 0.214 & 0.838 & 0.861 \\
PrS4 & 0.499 & 0.548 & 0.217 & 0.840 & 0.856 \\
Innovativeness & 0.541 & 0.397 & 0.215 & 0.839 & 0.809 \\
InS2 & 0.512 & 0.482 & 0.217 & 0.840 & 0.806 \\
InS3 & 0.272 & 0.777 & 0.227 & 0.848 & 0.774 \\
Information-seeking & 0.597 & 0.289 & 0.213 & 0.837 & 0.771 \\
IsS2 & 0.242 & 0.748 & 0.229 & 0.850 & 0.751 \\
IsS3 & 0.498 & 0.299 & 0.219 & 0.842 & 0.701 \\
Cosmopoliteness & 0.614 & 0.394 & 0.212 & 0.836 & 0.851 \\
CoS2 & 0.532 & 0.488 & 0.216 & 0.840 & 0.837 \\
CoS3 & 0.345 & 0.439 & 0.226 & 0.847 & 0.780 \\
Decision-making & 0.583 & 0.324 & 0.213 & 0.837 & 0.843 \\
DmS2 & 0.662 & 0.63 & 0.209 & 0.834 & 0.859 \\
DmS3 & 0.353 & & 0.225 & 0.846 & 0.797 \\
Test scale & & $\mathbf{0 . 2 1 8}$ & $\mathbf{0 . 8 4 8}$ & $\mathbf{0 . 8 1 0}$ \\
\hline N & & & & & \\
\hline
\end{tabular}

Note: AIC: Average Inter - items Covariance, KMO: Kaiser - Meyer - Olkin Source: Field data (2019)

Table 4 provides information on factor analysis for the six different entrepreneurial behavior dimensions. The factor loadings for each dimension were very good. Literature postulates that the value of uniqueness more than 0.60 is considered as high, and it also means that the factors did not well explain those variables. 
Entrepreneurial behavior dimensions such as risk-taking 1 and 4, innovativeness 2, information-seeking behavior 4, and decision-making ability 3 were not well explained by their respective factors. Therefore, they were removed before further analysis. The overall test scale for average inter-items covariance was 0.218 , which means that there are positive but weak correlations between each item. It is so because every item correlates with each other in a low stream. The total Cronbach alpha, which is the reliability coefficient, was 0.848 for 20 individual dimensions. It means that the data was reliable for the study. The Kaiser-Meyer-Olkin (KMO) for the entrepreneurial behavior dimension was 0.810 , indicating that the sampling was adequate for principal component analysis. Dendup et al. (2017) argue that KMO between 0.80 and 0.90 is well perfect for modeling.

\section{Entrepreneurial Behavior Index}

Entrepreneurial Behavior Index was used to describe the three different behavior skills of smallholder potato farmers in Nakuru County, Kenya.

Table 5: Distribution of entrepreneurial behavior skills County $(n=267)$

\begin{tabular}{|c|c|c|c|c|c|c|}
\hline Attributes & Categories & Score range & Mean & S.D. & Frequency & Percent \\
\hline \multirow{3}{*}{ Risk-taking ability } & Low & Below 11 & 15.04 & 3.79 & 50 & 18.7 \\
\hline & Medium & $11-19$ & & & 153 & 57.3 \\
\hline & High & Above 19 & & & 64 & 24 \\
\hline \multirow[t]{3}{*}{ Proactiveness behavior } & Low & Below 8 & 12.84 & 4.47 & 58 & 21.7 \\
\hline & Medium & $8-17$ & & & 166 & 62.2 \\
\hline & High & Above 17 & & & 43 & 16.1 \\
\hline \multirow[t]{3}{*}{ Innovativeness behavior } & Low & Below 3 & 6.23 & 2.85 & 63 & 23.6 \\
\hline & Medium & $3-9$ & & & 155 & 58.1 \\
\hline & High & Above 9 & & & 49 & 18.4 \\
\hline \multirow[t]{3}{*}{ Information-seeking behavior } & Low & Below 5 & 8.55 & 3.6 & 74 & 27.7 \\
\hline & Medium & $5-12$ & & & 168 & 62.9 \\
\hline & High & Above 12 & & & 25 & 9.4 \\
\hline \multirow[t]{3}{*}{ Cosmopoliteness behavior } & Low & Below 5 & 8.86 & 4.25 & 79 & 29.6 \\
\hline & Medium & $5-13$ & & & 133 & 49.8 \\
\hline & High & Above 13 & & & 55 & 20.6 \\
\hline \multirow[t]{3}{*}{ Decision-making ability } & Low & Below 7 & 10.68 & 3.42 & 54 & 20.2 \\
\hline & Medium & $7-14$ & & & 178 & 66.7 \\
\hline & High & Above 14 & & & 35 & 13.1 \\
\hline
\end{tabular}

Source: Field data (2019)

The results in Table 5 show that the majority (57.3\%) of potato farmers were medium risk-takers, $24 \%$ were high risk-takers, and $18.70 \%$ were low risk-takers. This implies that potato farmers take risks in trying new seed varieties and new production techniques. The possible reason is that most of the respondents have basic primary education and belonged to the middle age group. The results concur with Rituraj et al. (2015) and Ram et al. (2016), who pointed out that most vegetable farmers had medium risk-taking behavior followed by high risktaking behavior and low risk-taking in the Jorhat District of Assam and India.

Smallholder potato farmers possessed (62.2\%) medium proactiveness behavior. Some growers had $21.7 \%$ representing low proactiveness behavior, and $16.1 \%$ had high proactiveness behavior. This implies that most of the potato farmers failed to identify market opportunities ahead of other farmers and failed to look for where to market potatoes before engaging in potato farming. The possible reason is that most of the farmers were females who feared to search for untapped market opportunities due to their basic education level. The result contends with Hajong (2014), who established that the majority of smallholder farmers possessed very low proactiveness, low proactiveness behavior, medium, high, and very high proactiveness behavior in India. 
More than half $(58.1 \%)$ of smallholder potato farmers had medium innovativeness behavior accompanied by low $23.6 \%$ and $18.4 \%$ high innovativeness behavior. The results show that most farmers were not innovative in using locally available materials to control weeds, pests, and diseases. These contributed to the high pests and diseases on their potato farms and resulted in the production of one potato variety. The low innovativeness behavior can be attributed to the low farming experience and size of potato farms. The result contrasts with Mariammal and Seethalakshmi (2017), who found that most dairy women farmers had high innovativeness followed by medium and low innovativeness behavior in Tamil Nadu.

Most $(62.9 \%)$ of the smallholder potato farmers had medium information-seeking behavior, $27.7 \%$ had high and $9.4 \%$ low information-seeking behavior. The results found that smallholder potato farmers access information on potato farming through social media platforms. This is so because most of the respondents had a basic education level and understands the communication purposes in potato farming. The findings are similar to Rituraj et al. (2015), who discovered that most smallholder farmers had medium information-seeking behavior followed by high information-seeking and low information-seeking behavior in the Jorhat district of Assam.

Most smallholder potato farmers had medium (49.8\%) cosmopoliteness behavior followed by low (29.6\%) and high $(20.6 \%)$ level of cosmopoliteness. The low cosmopoliteness means that farmers did not seek information outside the farming community to improve potato farming. Furthermore, they failed to attend agricultural shows, conferences, and field days outside their communities to gain more knowledge on potato farming management. This could be due to the age differences of the respondents since most of the smallholder farmers were middle-aged farmers. The findings are consistent with Mariammal and Seethalakshmi's (2017) studies, which indicated that dairy farmers had a medium level of cosmopoliteness, low and high cosmopoliteness behavior in Tamil Nadu.

About $66.7 \%$ of smallholder potato farmers possessed a medium level of decision-making ability. This is followed by low decision-making ability with $20.2 \%$ and high decision-making ability $13.1 \%$. It can be deduced that most of the farmers did not make appropriate decisions on growing certified seeds. Although some potato farmers followed good agricultural practices, they feared to insure their potato farming in natural disasters. The possible reason is most of the respondents were females and landowners, so they did not consult their husbands regarding what to cultivate on the farmland. The findings conform to Rituraj et al. (2015), who indicated that most vegetable producers possessed moderate decision-making ability followed by good decision-making and low decision-making ability in the Jorhat district of Assam.

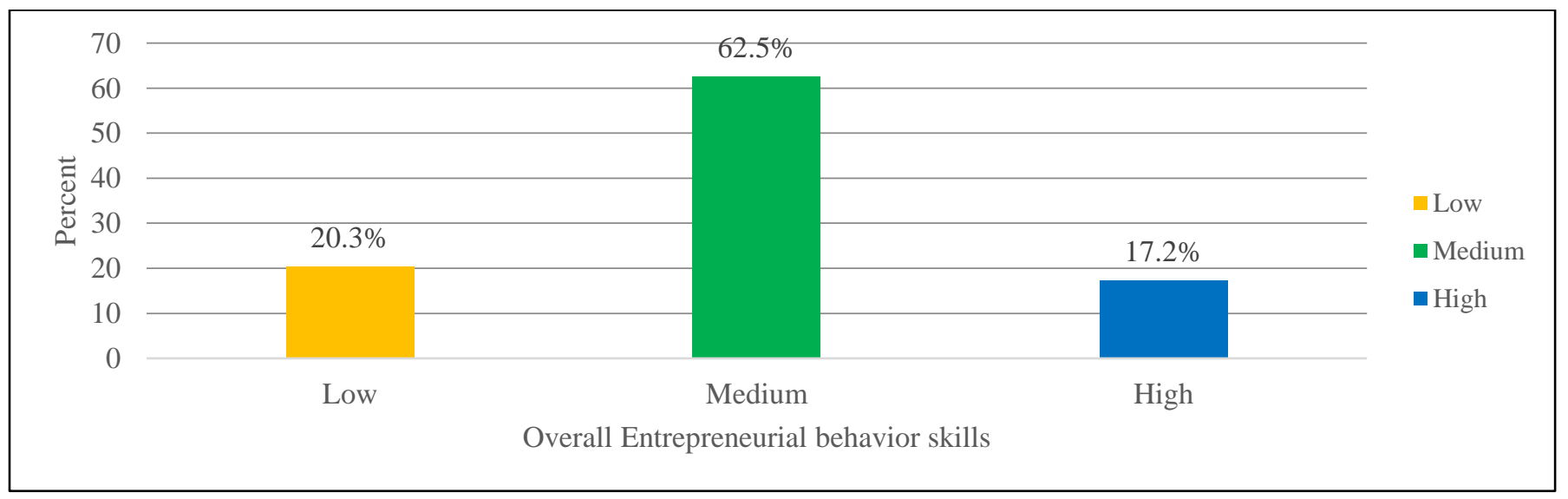

Figure 2: Overall entrepreneurial behavior skills of smallholder potato farmers in Nakuru County 
The study shows that $62.5 \%$ of smallholder potato farmers had medium behavior, followed by low (20.3\%) and high entrepreneurial behavior (17.2\%). This medium level of overall entrepreneurial behavior could be attributed to poor personal profile since most of them had primary education, were females at the same time married, and had age groups ranging from 36-55 years. Besides, most potato farmers had less than five years' experience in potato farming. The findings conform to Porchezhiyan et al. (2014), who found that women farmers in dairy production had a medium level of entrepreneurial behavior followed by low and high entrepreneurial behavior. The finding is similar to Mariammal and Seethalakshmi (2017) and Wanole et al. (2018), who established that most dairy farmers and banana growers possessed medium, poor, and good entrepreneurial behavior.

\section{Relationship between entrepreneurial behavior skills and socio-economic characteristics}

Correlation analysis was used to determine the relationship between risk-taking ability, proactiveness behavior, innovativeness behavior, information-seeking behavior, cosmopoliteness behavior and decision-making ability, and head of farm household, gender, marital status, age, education level, household size, type of land ownership, total farm size, annual income, and farming experience.

\section{Table 6: Correlation coefficient between entrepreneurial behavior and socio-economic characteristics $(n=267)$}

\begin{tabular}{lll}
\hline $\mathbf{S} / \mathbf{n o}$ & Independent variables & r value \\
\hline $\mathbf{1 .}$ & Head of the farm household & 0.052 \\
$\mathbf{2 .}$ & Gender & $\mathbf{- 0 . 1 2 7 *}$ \\
$\mathbf{3 .}$ & Marital status & -0.120 \\
$\mathbf{4 .}$ & Age & 0.027 \\
$\mathbf{5 .}$ & Education level & $\mathbf{- 0 . 1 3 2 *}$ \\
$\mathbf{6 .}$ & Household size & -0.120 \\
$\mathbf{7 .}$ & Type of land ownership & 0.009 \\
$\mathbf{8 .}$ & Total land size & 0.034 \\
$\mathbf{9 .}$ & Annual income & $\mathbf{- 0 . 2 3 7 *}$ \\
$\mathbf{1 0 .}$ & Farming experience & -0.030 \\
$\mathbf{1 1 .}$ & Scale of production & $\mathbf{- 0 . 1 4 9 *}$ \\
\hline
\end{tabular}

Note: $*$ and $* *$ Correlation coefficient is statistically significant at the 0.05 and 0.01 level (2-tailed).

Source: Field data (2019)

The results from Table 6 reveal that gender was negatively and significantly correlated with entrepreneurial behavior at a $1 \%$ significance level. It has been observed that most of the respondents were female potato farmers. The possible reason for their negative attitude towards entrepreneurial behavior could be attributed to their more responsibility in taking care of the family since they were married. These made them not seek production information from extension officers, participate in farmer group activities, and attending agricultural shows and trips outside their farming community.

The education level of smallholder potato farmers was found to have a negative and significant correlation with entrepreneurial behavior skills at a 5\% significance level. This means that most of the farmers had a basic level of education. The poor educational background prevents farmers from taking risks and making appropriate production decisions to adopt new, improved seeds, s leading to increased potato productivity. The findings disagree with Bhosale et al. (2014), who found that education level positively correlates with dairy farmers' entrepreneurial behavior. 
Annual income negatively and significantly correlated with entrepreneurial behavior of smallholder potato farmers at a 5\% significance level. The result shows that smallholder potato farmers earned low farm income from potato farming. The main reason is that smallholder farmers did not get their main source of income from potato farming; they tend to allocate a small portion of their farmlands for potato production. The findings are not in line with (Bhosale et al., 2014) and Rakesh, Singh, and Sangwan (2017), who stated that annual income positively correlates with dairy farmers' entrepreneurial behavior.

The production scale negatively correlated with the entrepreneurial behavior of smallholder potato farmers at a $1 \%$ significance level. It can be observed from the data that farmers cultivate potatoes on small land and were not willing to take risks in expanding the scale of production due to their poor farming experience. Chouhan (2015) cited that the area under tomato crop has shown a significant positive relationship with the entrepreneurial behavior of the tomato growers.

\section{Conclusion and Recommendations}

The study concluded that most smallholder potato farmers possessed a medium level of risk-taking ability, proactiveness, innovativeness, information-seeking behavior, cosmopoliteness, and decision-making ability due to their poor education levels, gender differences, low annual farm incomes, poor farming experiences, and low scale of potato production. The study recommends that smallholder farmers be provided with adult education on modern agricultural practices and technologies to increase their chance of adoption tendency leading to high potato productivity and profitability. Also, smallholder potato farmers need to be supported with technical skills and capital to expand potato farming enterprises. Furthermore, smallholder potato farmers need to increase production scale through the allocation of more farmlands leading to high annual farm income. The study suggests that entrepreneurial training with practical demonstration and effective communication skills should be used to empower and promote the development of entrepreneurial behavior qualities among smallholder potato farmers.

Funding: The authors are grateful to the Regional Universities Forum for Capacity Building in Agriculture (RUFORUM) and Transforming African Agricultural Universities for funding this research and contributing to Africa's growth and development.

Conflicts of Interest: The author declares no conflict of interest.

\section{References}

Abeyrathne, H., \& Jayawardena, L. (2014). Impact of group interactions on farmers' entrepreneurial behavior. Economics and Management.

Bhosale, S., Deshmukh, A., Godse, S., \& Shelake, P. (2014). Entrepreneurial behavior of dairy farmers. Advance Research Journal of Social Science, 5(2), 171-174.

Chouhan, O. P. (2015). A study on entrepreneurial behavior of tomato grower's in Sehore block of Sehore district (MP). JNKVV.

Dendup, T., Gyeltshen, T., Penjor, L., \& Dorji, P. (2017). The Factors Affecting Success of Small AgroEnterprises in Bhutan. Asian Journal of Agricultural Extension, Economics \& Sociology, 1-11.

Dillon, W. R., \& Goldstein, M. (1984). Multivariate analysis methods and applications.

Fayaz. (2015). Impact of Entrepreneurial Behaviour on Farming Performance of Cotton Growers In Kurnool District of Andhra Pradesh. Acharya NG Ranga Agricultural University.

Field, A. P. (2009). Discovering statistics using SPSS for Windows: Advanced techniques for the beginner: Sage. Giridhara. (2013). A study on entrepreneurial behavior of women entrepreneurs in Mandya district. (MSc Agriculture). University of Agricultural Sciences, Bangalore, India 
GOK. (2012). National Agribusiness Strategy: Making Kenya's Agribusiness Sector a Competitive Driver of Growth. Kilimo House, Cathedral Road, Nairobi, Kenya.

GOK. (2018). Nakuru County integrated development plan. (Vol. 1): Republic of Kenya Nakuru County First County Integrated Development Plan (2018-2022).

Guilford, J. P. (1967). The nature of human intelligence.

Gurjar, R. S., Gour, C., Dwivedi, D., \& Badodiya, S. (2017). Entrepreneurial behavior of potato growers and constraints faced by farmers in production and marketing of potato and their suggestion. Plant Archives, 17(1), 427-432.

Guttman, L. (1954). Some necessary conditions for common-factor analysis. Psychometrika, 19(2), 149-161.

Hajong, D. (2014). A study on agripreneurship behavior of farmers. Ph.D. Thesis, Division of Agricultural Extension Research Institute, New Delhi, India.

Jelle, O. (2016). The influence of entrepreneurship education on entrepreneurial behavior. (MSc Thesis). University of Ghent, Belgium,

Kaguongo, W., Nyangweso, A., Mutunga, J., Nderitu, J., Lunga'ho, C., Nganga, N., . . Njane, P. (2013). A policymakers' guide to crop diversification: FAO.

Kahan, D. (2013). Entrepreneurship in farming. Farm management extension guide(5).

Kaiser, H. F. (1970). A second generation little jiffy. Psychometrika, 35(4), 401-415.

KEPHIS.(2019). Nakuru County in drive to increase uptake of certified potato seed. Retrieved from https://www.kbc.co.ke/tag/potato-seed/.com

Khalid, B., Maalu, J., Gathungu, J., \& McCormick, D. (2016). Entrepreneurial Behaviour, Institutional Context, and Performance of Micro and Small Livestock Enterprises in North Eastern Region of Kenya. Global Journal of Management And Business Research.

Konté, M. S., Ayuya, O. I., \& Gathungu, E. (2019). Effect of entrepreneurial behavior on farm performance among small-scale farmers: a case of Niono zone, Mali. Advances in Agricultural Science, 7(1), 24-39.

Kumar, S., Sharma, G., \& Yadav, V. (2013). Factors influencing entrepreneurial behavior of vegetable growers. Indian Res. J. Ext. Edu, 13(1).

Mariammal, R., \& Seethalakshmi, M. (2017). Entrepreneurial Behaviour Of Dairy Farm Women In Dindigul District of Tamil Nadu.

MOALFI. (2016). The National Potato Strategy from 2016 to 2020. Retrieved from https://npck.org.co.ke

Mubeena, M., Lakshmi, T., Prasad, S., \& Sunitha, N. (2017). Direct and Indirect Changes of Members of Podupu Laxmi Ikya Sangam. Asian Journal of Agricultural Extension, Economics \& Sociology, 1-6.

Mudiwa, B. (2018). A Review of the Entrepreneurial Behavior of Farmers: An Asian-African Perspective. Asian Journal of Agricultural Extension, Economics \& Sociology, 1-10.

Mwangi, S. C. (2010). The effects of market reforms on Irish potato price volatility in Nyandarua District, Kenya. University of Nairobi,

NPCK. (2016). Potato Variety Catalogue. . Retrieved from https://www.npck.org/books/.com

Okangi, F. P. (2019). The impacts of entrepreneurial orientation on the profitability growth of construction firms in Tanzania. Journal of Global Entrepreneurship Research, 9(1), 1-23.

Okello, J. J., Zhou, Y., Kwikiriza, N., Ogutu, S. O., Barker, I., Schulte-Geldermann, E., . . Ahmed, J. T. (2016). Determinants of the use of certified seed potato among smallholder farmers: the case of potato growers in central and eastern Kenya. Agriculture, 6(4), 55.

Omare, J. O. a. K., J.K. (2016). Effect of entrepreneurial skills on competitive advantage among small and medium size enterprises. International Journal of Economics, Commerce and Management, 7(5), 173-180.

Ondiba, H. A., \& Matsui, K. (2019). Social attributes and factors influencing entrepreneurial behaviors among rural women in Kakamega County, Kenya. Journal of Global Entrepreneurship Research, 9(1), 1-10.

Pallant, J. (2007). SPSS survival manual: A step-by-step guide to data analysis using SPSS version 15. Nova Iorque: McGraw Hill. 
Palma, C., Lopes (2009). Entrepreneurial behavior. . Journal of Enterprising Culture, 17(3), 323-349.

Porchezhiyan, S., Devi, M., \& Mathialagan, P. (2014). Correlates of Entrepreneurial Behavioral Components. Porchezhiyan, S., Devi, M., \& Mathialagan, P. (2016). Correlates of Entrepreneurial Behavioral Components.

Rakesh, A., Singh, S., \& Sangwan, S. (2017). Study on decision making ability and risk orientation among dairy farmers and correlates with their socio-economic and psychological characteristics. Haryana Veterinarian, 56(1), 77-82.

Ram, D., Singh, M., Chaudhary, K., \& Jayarani, L. (2016). Entrepreneurship behavior of women entrepreneurs in Imphal of Manipur. Indian Research Journal of Extension Education, 13(2), 31-35.

Rituraj, B., Borua, S., Deka, C., \& Borah, D. (2015). Entrepreneurial behavior of tribal winter vegetable growers in Jorhat district of Assam. Indian Research Journal of Extension Education, 15(1), 65-69.

Shrestha, N. (2021). Factor Analysis as a Tool for Survey Analysis. American Journal of Applied Mathematics and Statistics, 9(1), 4-11.

Taiy, R., Onyango, C., Nkurumwa, A., Ngetich, K., Birech, R., \& Ooro, P. (2016). Potato value chain analysis in Mauche Ward of Njoro Sub-County, Kenya. International Journal of Humanities and Social Science, 6(5), 129-138.

Tamminana, S., \& Mishra, O. (2017). Socio-economical dimensions of agripreneurs under ACABC scheme in Andhra Pradesh. Trends in Biosciences, 10(15), 2679-2682.

Verma, J. (2012). Data analysis in management with SPSS software: Springer Science \& Business Media.

Vora, D., Vora, J., \& Polley, D. (2012). Applying entrepreneurial orientation to a medium sized firm. International Journal of Entrepreneurial Behavior \& Research.

Wanole, S., Bande, K., Holkar, S., \& Mardane, R. (2018). Relational analysis of entrepreneurial behavior of banana growers. International Jr. of Chemical Studies, 6(3), 2407-2411.

Yamane, T. (1967). Problems to accompany" Statistics, an introductory analysis": Harper \& Row. 